
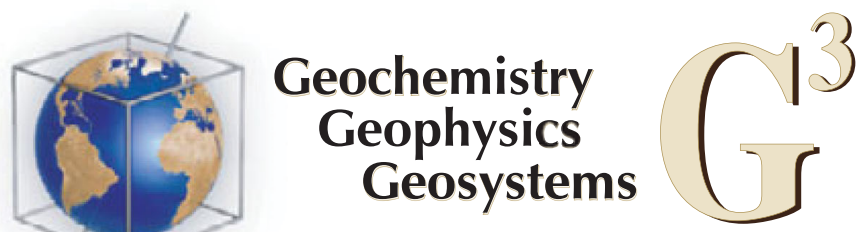

\title{
Water mass exchange between the Nordic seas and the Arctic Ocean on millennial timescale during MIS 4-MIS 2
}

\author{
Tine L. Rasmussen \\ Centre for Arctic Gas Hydrate, Environment and Climate, Arctic University of Norway, NO9037, Tromso, \\ Norway (tine.rasmussen@uit.no) \\ Erik Thomsen \\ Department of Geoscience, University of Aarhus, Aarhus, Denmark
}

\section{Tove Nielsen \\ Geological Survey of Denmark and Greenland, Copenhagen, Denmark}

[1] The climate of the last glaciation circa 65,000-25,000 years ago was interrupted by about 15 abrupt temperature fluctuations, the so-called Dansgaard-Oeschger events consisting of warm interstadials and cold stadials recorded in Greenland ice cores. The largest fluctuations occur in the North Atlantic region, but they have been registered over the most of the world. The events are linked to changes in deep water formation in the Nordic seas and North Atlantic, disrupting the thermohaline circulation. Yet, Dansgaard-Oeschger events have so far not been recorded north of the convection areas in the central Nordic seas, and it is not known if they affected the water exchange between the Nordic seas and the Arctic Ocean. In this study, we analyze core JM05-31GC from the northern Fram Strait at the very entrance to the Arctic Ocean. The core contains sediments from marine isotope stages (MISs) 4-2. The results show millennial timescale shifts in all the investigated proxies including the distribution of planktonic and benthic foraminifera, planktonic and benthic oxygen and carbon isotopes, and several sedimentological parameters. In JM05-31GC, the interstadials are characterized by relatively high surface and low bottom water temperatures, low content of ice-rafted debris, and well-ventilated bottom water. Stadials are characterized by the presence of icebergs and decreasing surface water and increasing bottom water temperatures due to increased inflow of Atlantic subsurface water. Ventilation decreased during Heinrich events and most stadials. The results show that the DansgaardOeschger events strongly affected the water exchange between the Nordic seas and the Arctic Ocean.

Components: 10,049 words, 7 figures, 1 table.

Keywords : Dansgaard-Oeschger events; Fram Strait; Nordic seas-Arctic Ocean exchange; millennial climate change.

Index Terms: 0473 Paleoclimatology and paleoceanography: Biogeosciences; 0454 Isotopic composition and chemistry: Biogeosciences; 0459 Macro- and micropaleontology: Biogeosciences; 3344 Paleoclimatology: Atmospheric Processes; 1041 Stable isotope geochemistry: Geochemistry; 4870 Stable isotopes: Oceanography: Biological and Chemical; 1605 Abrupt/rapid climate change: Global Change; 4901 Abrupt/rapid climate change: Paleoceanography; 4944 Micropaleontology: Paleoceanography; 8408 Volcano/climate interactions: Volcanology; 3030 Micropaleontology: Marine Geology and Geophysics.

Received 30 August 2013; Revised 4 December 2013; Accepted 22 December 2013; Published 00 Month 2014.

Rasmussen T. L., E. Thomsen, and T. Nielsen (2014), Water mass exchange between the Nordic seas and the Arctic Ocean on millennial timescale during MIS 4-MIS 2, Geochem. Geophys. Geosyst., 15, doi:10.1002/2013GC005020. 


\section{Introduction}

[2] The climate of the last glacial period was extremely unstable. Studies of oxygen isotope variability in the Greenland ice cores have demonstrated that the climate of the coldest part of the glaciation comprising marine isotope stages (MISs) 4-2 was interrupted by numerous abrupt, millennial-scale temperature fluctuations, the socalled Dansgaard-Oeschger events [Dansgaard et al., 1993]. Within a few years the atmospheric temperatures over Greenland could increase by more than $10^{\circ} \mathrm{C}$ [Johnsen et al., 2001]. However, the warm periods were short, and after a few hundred years the cold climate returned. The warm periods are termed interstadials; the cold periods are termed stadials. The largest excursions and the most rapid changes occur in the North Atlantic region, but they have been traced over most of the world including the tropical Atlantic, Indian, and Pacific Oceans. Several investigations have shown that the events are closely linked to changes in convection and deep water formation in the Nordic seas and North Atlantic affecting the strength of the thermohaline Atlantic Meridional Overturning Circulation and the transport of heat to the north [Broecker et al., 1990; Rasmussen et al., 1996a, 1996b; McManus et al., 2004] (Figure 1a).

[3] In the Nordic seas, changes in the ocean circulation pattern related to Dansgaard-Oeschger events have only been thoroughly documented in cores from the southern and southeastern parts. No studies have demonstrated millennial-scale circulation changes in the northern part north of the main convection sites in the Iceland and Greenland Seas. It is therefore not known whether-or to what extent - the Dansgaard-Oeschger events are related to the exchange of water masses between the Nordic seas and the Arctic Ocean.

[4] One of the reasons for this lack of information is the strong dissolution of biogenic carbonates in most cores from the northernmost part of the Nordic seas and the Arctic Ocean, leaving large time gaps in the stratigraphic record of most paleoceanographic and paleoclimatic proxies [Haake and Pflaumann, 1989; Bauch et al., 2001]. Paleoceanographic reconstructions from this area are therefore normally long ranging and of moderate to low resolution linked to orbital timescales [Hebbeln et al., 1994; Dokken and Hald, 1996; Bauch, 1997; Antonov et al., 1997; Knies et al., 1999; Vogt et al., 2001; Spielhagen et al., 2004]. Heinrich events [Heinrich, 1988] have been identified in a few cores, but with considerable stratigraphic uncertainty [Dokken and Hald, 1996; Hanslik et al., 2010].

[5] The aim of the present investigation is to reconstruct the paleoceanographic conditions in the Fram Strait and the exchange of water masses between the Nordic seas and the Arctic Ocean from late MIS 4 to MIS 2 (circa 65,00025,000 years) on a millennial timescale. The study is focused on gravity core JM05-31GC retrieved at intermediate water depth in the northern Fram Strait close to $80^{\circ} \mathrm{N}$ at the entrance to the Arctic Ocean (Figure 1a). This core is located in the flow path of the northward flowing Atlantic Water of the West Spitsbergen Current. The core contains a better preserved record of biogenic carbonate than normally seen in this area. We have analyzed the core for variations in several biological, geochemical, and sedimentological parameters, including planktonic and benthic foraminiferal faunas, stable oxygen and carbon isotopes based on planktonic and benthic foraminifera, and the concentration of ice-rafted debris (IRD). In addition, we have calculated subsurface water temperature (SWT) and bottom water temperature (BWT) using transfer functions applied to both benthic and planktonic foraminiferal faunas.

\section{Oceanographic Setting}

[6] The eastern part of the Fram Strait is dominated by the warm (summer temperature approximately $4-6^{\circ} \mathrm{C}$ ) and saline Atlantic water of the West Spitsbergen Current flowing northward into the Arctic Ocean [Aagaard et al., 1987] (Figure 1a). The western part is dominated by the cold Polar Water of the East Greenland Current flowing southward. Centrally in the Fram Strait, the Atlantic and Polar surface waters mix and generate Arctic water, which is slightly colder and less saline than the Atlantic surface water [Hop et al., 2006] (Figure 1a). The three surface water masses are separated by two oceanic fronts, the Polar front to the west and the Arctic front to the east. The zone of Arctic surface water also constitutes the marginal ice zone (MIZ) [Vinje, 1977], with its high surface productivity [e.g., Smith et al., 1987].

[7] In the northern Fram Strait, the Atlantic surface water subducts beneath the cold, ice-covered polar water of the Arctic Ocean and continues as a subsurface current, now termed Atlantic 


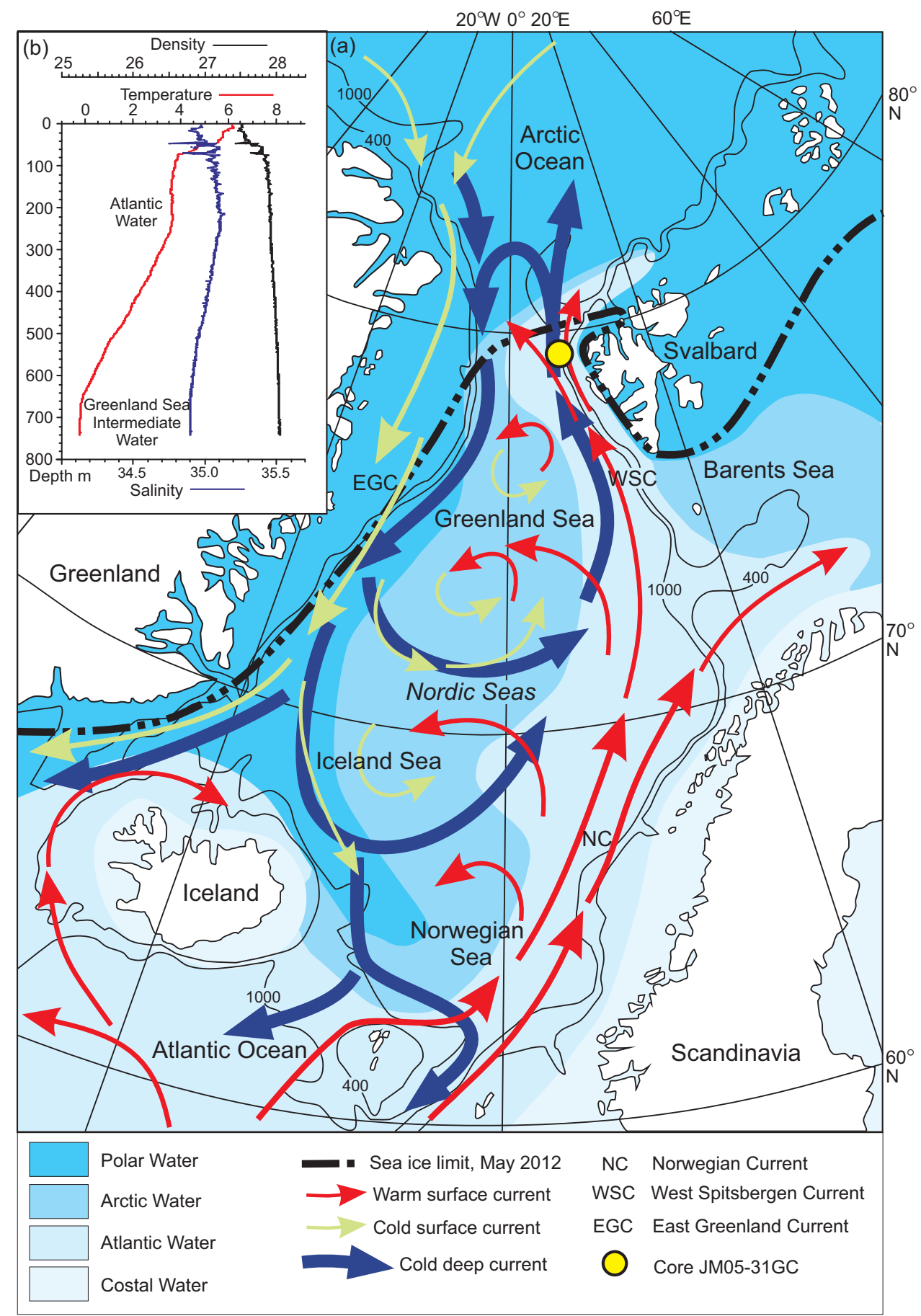

Figure 1. (a) Map of the Nordic seas showing major surface and bottom currents and the location of core JM05-31GC in the northeastern part of the Fram Strait. (b) CTD profile (conductivity, temperature, depth) taken in August 2012 at the core site.

Intermediate Water [Rudels, 1987; Rudels et al., 2000, 2005]. In August 2012, the warmest core of the Atlantic water reached a temperature of $6.3^{\circ} \mathrm{C}$ at the study site (Figure 1b). The water masses below the Atlantic Water consist of Greenland Sea Intermediate Water and Greenland Sea Deep
Water [Hopkins, 1991]. The cold Greenland Sea intermediate water $\left(-0.9^{\circ} \mathrm{C}\right)$ is generated by convection in the Greenland Sea. All three water masses flow northward through the Fram Strait into the Arctic Ocean steered by the topography of the sea bottom (Figure 1). In the Fram Strait, 


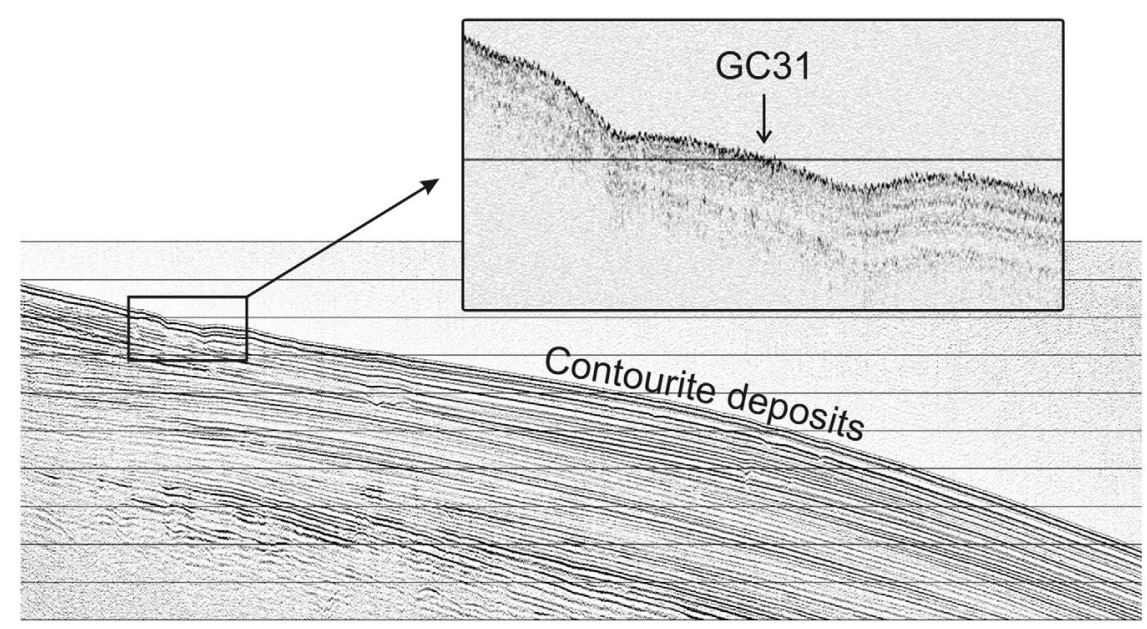

Figure 2. Seismic profile from the northwestern Svalbard slope showing contourite deposits. (insert) Acoustic (3.5 kHz echosounding) showing details from location of core JM05-31GC.

during summer time, the mixing zone between the warm Atlantic water and the cold convected water is situated between 300 and $600 \mathrm{~m}$ water depth (Figure 1b).

[8] The flow of the water masses generates relatively strong bottom currents, and the western slope of Svalbard is known for the deposition of contourite bodies [e.g., Eiken and Hinz, 1993; Howe et al., 2008]. The investigated core was retrieved from one of these contourites (Figure 2).

\section{Material and Methods}

[9] The $386 \mathrm{~cm}$ long gravity core, JM05-31GC, was taken at $785 \mathrm{~m}$ water depth (position $79.36 .5^{\circ} \mathrm{N}, 07.43 .0^{\circ} \mathrm{E}$ ) northwest of Sjubrebanken (Figures 1 and 2). The deposits are predominantly hemipelagic consisting of alternating layers of clayey silt and sandy clays. Sediments of Holocene age are absent. This is typical for the western slope and shelf of Svalbard above $\sim 1200$ m water depth, due to strong Holocene bottom currents [Elverhøi et al., 1995; Jessen et al., 2010].

[10] Magnetic susceptibility was measured using a multi-sensor core logger before opening. The core was described, and sediment colors were determined using the Munsell Soil Color Chart. The core was subsequently sampled in $0.7 \mathrm{~cm}$ thick slices at $1,2,3$, or $5 \mathrm{~cm}$ intervals. The samples were weighed and dried at $50^{\circ} \mathrm{C}$ and weighed again. They were subsequently wet sieved over mesh sizes 63 and $100 \mu \mathrm{m}$, and the residues were dried and weighed. The residues $>100 \mu \mathrm{m}$ were spread evenly over a picking tray, and $~ 300$ planktonic and $\sim 300$ benthic foraminifera were counted and identified for each sample. The percentage of fragmented planktonic foraminifera relative to whole specimens was calculated as a measure for the preservation of calcium carbonate [e.g., Berger et al., 1982; Le and Shackleton, 1992; Conan et al., 2002; Pfuhl and Shackleton, 2004]. The concentration of planktonic and benthic foraminifera per gram dry weight sediment was calculated. The samples were then dry sieved over $150 \mu \mathrm{m}$ mesh size for counts of IRD and recounts of planktonic foraminifera for calculations of absolute subsurface temperatures based on transfer functions (see below). Between 150 and 300 mineral grains and $\sim 300$ specimens of planktonic foraminifera were counted from each sample.

[11] Stable isotope measurements were performed on the planktonic foraminiferal species Neogloboquadrina pachyderma $\mathrm{s}$ and the benthic foraminiferal species Cassidulina teretis at Woods Hole Oceanographic Institution [see Ostermann and Curry, 2000]. Stable isotopes were measured on the benthic foraminiferal species Cibicides lobatulus and Cibicidoides pachyderma at the University of Bergen. The measurements on the two latter species were corrected for isotopic disequilibrium of $+0.64 \%$ [Shackleton, 1974], while N. pachyderma $\mathrm{s}$ and $C$. teretis were not corrected.

[12] Subsurface and bottom water temperatures were calculated based on transfer functions performed on the planktonic (size fraction $>150 \mu \mathrm{m}$ ) and benthic foraminiferal census counts, respectively. We used the C2 program [Juggins, 2007] applying the WAPLS (weighted average partial least squares) technique. We used two components 
Table 1. AMS $-{ }^{14} \mathrm{C}$ Dates and Calibrated Ages of JM05$31 \mathrm{GC}$

\begin{tabular}{|c|c|c|c|}
\hline $\begin{array}{l}\text { Core Depth } \\
(\mathrm{cm})\end{array}$ & Species & $\begin{array}{c}\text { Age } \\
\left({ }^{14} \mathrm{C} \pm 1 \sigma\right)\end{array}$ & $\begin{array}{l}\text { Calibrated } \\
\text { Age } \pm 1 \sigma\end{array}$ \\
\hline 49.5 & $\begin{array}{l}\text { Neogloboquadrina } \\
\text { pachyderma } \mathrm{s}\end{array}$ & $18,550 \pm 120$ & $21,680 \pm 225$ \\
\hline 75.5 & $\begin{array}{l}\text { Neogloboquadrina } \\
\text { pachyderma } \mathrm{s}\end{array}$ & $19,970 \pm 130$ & $21,680 \pm 225$ \\
\hline 123.5 & $\begin{array}{l}\text { Neogloboquadrina } \\
\text { pachyderma } \mathrm{s}\end{array}$ & $21,830 \pm 160$ & $25,630 \pm 290$ \\
\hline 197.5 & Arca sp. & $29,450 \pm 700$ & $33,720 \pm 835$ \\
\hline 237.5 & $\begin{array}{l}\text { Bivalve and benthic } \\
\text { foraminifera }\end{array}$ & $34,100 \pm 650$ & $38,350 \pm 910$ \\
\hline 375.5 & $\begin{array}{l}\text { Neogloboquadrina } \\
\text { pachyderma } \mathrm{s}\end{array}$ & $49,500 \pm 550$ & \\
\hline
\end{tabular}

for planktonic calculations and one component for the benthic calculations. The selected number of components follows the recommendations of Birks [1998] and Sejrup et al. [2004], respectively. For the planktonic temperatures we used the Multiproxy Approach for the Reconstruction of the Glacial Ocean surface (MARGO) database [Pflaumann et al., 2003; Kucera et al., 2005] together with temperatures from the 2009 World Ocean Atlas [Locarnini et al., 2010]. The summer SWT was calculated for $75 \mathrm{~m}$ water depth. This depth generally represents the average water depth at which the planktonic foraminiferal assemblages live [Hemleben et al., 1989]. The BWTs were calculated using a database for the depth interval 250$2000 \mathrm{~m}$ in the North Atlantic realm. The database consists of samples extracted from the database of Sejrup et al. [2004] with the addition of samples from the cold realm from Belanger and Streeter [1980], Sejrup et al. [1981], Mackensen [1985], Mackensen et al. [1985], Hald and Steinsund [1992], and Saher et al. [2009] and samples from the warmer realm using published records from Ireland, Bay of Biscay, off Portugal, the central North Atlantic Ocean, the east coast of Canada, and the United States [Seiler, 1975; Schafer and Cole, 1982; Hermelin and Scott, 1985; Weston, 1985; Corliss, 1991; Austin and Evans, 2000; Fontanier et al., 2002; Schönfeld, 2002; Sun et al., 2006; Margreth et al., 2009; Mojtahid et al., 2010; Duros et al., 2011; Schröder-Adams and van Rooyen, 2011].

[13] Accelerator Mass Spectrometry (AMS)- ${ }^{14} \mathrm{C}$ dates were measured at the AMS Dating Centre at the University of Aarhus, Denmark, on monospecific samples of $N$. pachyderma s, or on bivalves and mixed benthic foraminiferal assemblages (Table 1). The upper three AMS- ${ }^{14} \mathrm{C}$ dates and the magnetic susceptibility have been published previ- ously in Jessen et al. [2010]. All dates with the exception of the lowermost date at $375.5 \mathrm{~cm}$ (infinite age; see Table 1) were calibrated to calendar age using the Calib 6.01 program and the Marine09 calibration data, which operates with a standard reservoir correction of -405 years [Stuiver and Reimer, 1993; Reimer et al., 2009]. The age model was constructed by assuming linear sedimentation rates between dating points (Figure 3 ). For the interval below the oldest reliable ${ }^{14} \mathrm{C}$ date at $237.5 \mathrm{~cm}$ we used the position of the geomagnetic Laschamps event at 255-265 cm [Snowball et al., 2007], which is dated to circa 41,000 years B.P. in the GISP2 ice core [e.g., Laj et al., 2002], and the position of the MIS 4-MIS 3 boundary, which is dated to circa 60,000 years B.P. [Martinson et al., 1987] (Figures 3 and 4).

\section{Results}

\subsection{Lithology, Age, and Stratigraphy}

[14] The top $10 \mathrm{~cm}$ of core JM05-31GC consists of large stones and gravel, and this unit is interpreted as a lag deposit (Figure 4). From $\sim 15 \mathrm{~cm}$ downcore the sediments appear undisturbed. The uppermost part from approximately 15 to $80 \mathrm{~cm}$ consists of light grey, foraminifer-rich, slightly sandy mud. Below this unit follows a $30 \mathrm{~cm}$ thick layer of dark grey unsorted gravel, sand, silt, and clay with low magnetic susceptibility. The

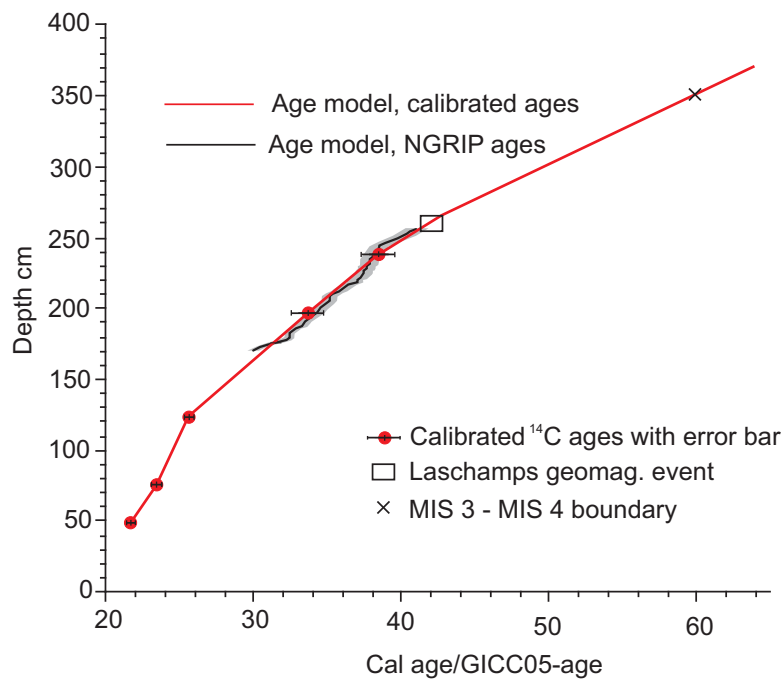

Figure 3. Age-depth plot for core JM05-31GC. Red line is plotted versus calibrated ${ }^{14} \mathrm{C}$ years, age of Laschamps paleomagnetic event, and age of the MIS 3-MIS 4 boundary. Black line is plotted versus ice core age after tuning (see text for explanation). 


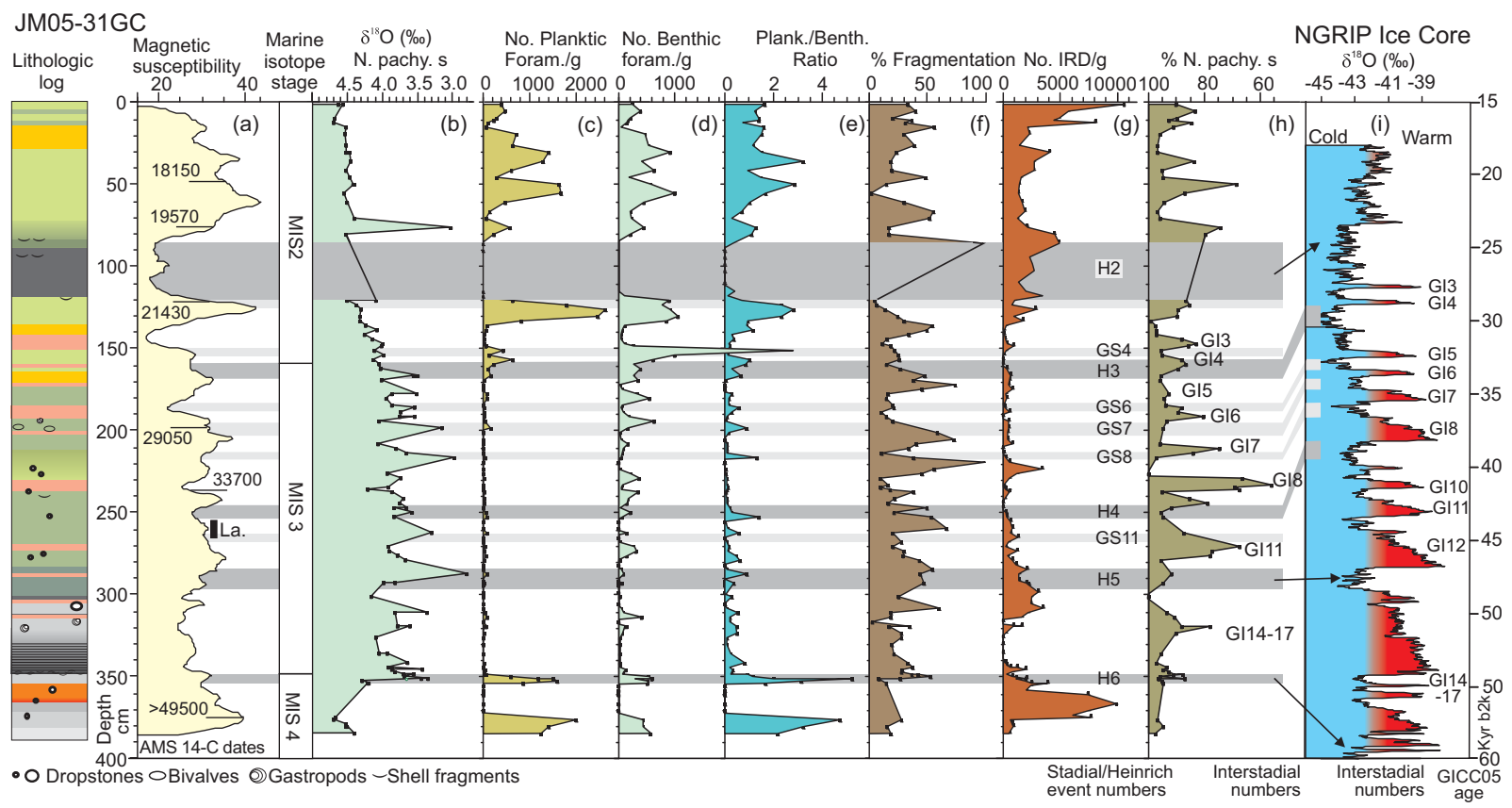

Figure 4. Lithological log and records from core JM05-31GC plotted versus centimeter downcore. (a) Magnetic susceptibility measured using loop sensor (AMS- ${ }^{14} \mathrm{C}$ dates are indicated). La. marks position of Laschamps paleomagnetic event. (b) Planktonic $\delta^{18} \mathrm{O}$ values measured in Neogloboquadrina pachyderma $\mathrm{s}$. Concentration of (c) planktonic and (d) benthic foraminifera $(>100 \mu \mathrm{m})$ in number per gram dry weight (dwt) sediment. (e) Planktonic/benthic ratio. (f) Percent fragmentation. (g) Concentration of ice-rafted debris (IRD; $>150 \mu \mathrm{m})$ in number per gram dwt sediment. (h) Relative abundance of $N$. pachyderma $\mathrm{s}(>100 \mu \mathrm{m}$; note inverse scale). (i) $\delta^{18} \mathrm{O}$ values measured on NGRIP ice core on GICC05 timescale before $2 \mathrm{ka}$ [Svensson et al., 2008] (Greenland stadial (GS) and interstadial (GI) numbers are indicated). Marine isotope stages (MISs) are indicated. Light grey bars mark stadials. Dark grey bars mark Heinrich events.

sediments from the central part of the core between 120 and $300 \mathrm{~cm}$ are very colorful and consist of light greenish-grey to dark greenish-grey (GLEY N $5 / 5 \mathrm{GY} 5 / 1$ to $\mathrm{N} 65 \mathrm{G} 6 / 1$ ) sandy silt alternating with layers of pink (10R 6/6) clay and brownish yellow (10YR 6/8) silty clay (Figure 4). Below 300 $\mathrm{cm}$ the sediments are predominantly bluish grey (GLEY N 5 BG 5/1). From approximately 320 to $345 \mathrm{~cm}$ the sediments are laminated and dark bluish grey (GLEY N 45B 4/1; Figure 4). From 352 to $362 \mathrm{~cm}$, the bluish-grey deposits are intercalated by a bright yellowish-red sandy layer (10YR 5/8) devoid of foraminifera (Figure 4).

[15] The AMS- ${ }^{14} \mathrm{C}$ dates in combination with the $\delta^{18} \mathrm{O}$ record show that the core comprises MIS 2, MIS 3, and the upper part of MIS 4 (Figures 4 and 5). High planktonic and benthic $\delta^{18} \mathrm{O}$ and $\delta^{13} \mathrm{C}$ values and two AMS- ${ }^{14} \mathrm{C}$ dates of 18,150 and 19,570 years, respectively, refer the upper part from 10 to $80 \mathrm{~cm}$ to the Last Glacial Maximum [Martinson et al., 1987] (Figures 4 and 6). Coarsegrained deposits with low magnetic susceptibility similar to the layer from 80 to $120 \mathrm{~cm}$ occur along the entire west coast of Svalbard dated to between 20,000 and $22,000{ }^{14} \mathrm{C}$ years [Elverhøi et al., 1995; Andersen et al., 1996; Jessen et al., 2010]. The layer was deposited after the SvalbardBarents Sea Ice Sheet reached the shelf edge [see Jessen et al., 2010, and references therein]. The interval from 160 to $354 \mathrm{~cm}$ is characterized by fluctuating isotope values with shifts in amplitudes $>1 \%$ (Figure 4). Highly variable values are typical for MIS 3 in the North Atlantic Ocean and Nordic seas [Bond et al., 1993; Dokken and Hald, 1996; van Kreveld et al., 2000; Vogt et al., 2001]. This places the boundary between MIS 2 and MIS 3 at $\sim 140 \mathrm{~cm}$. The lower part of the core below $\sim 354 \mathrm{~cm}$ has high $\delta^{18} \mathrm{O}$ values. This part probably correlates with MIS 4 [e.g., Martinson et al., 1987; Vogt et al., 2001] (see also section 4.2).

\subsection{Overall Patterns in the Distribution of Foraminifera, Stable Isotopes, and IRD}

[16] Two relatively thick layers in MIS 2 and in MIS 4, respectively, and several thinner layers in 


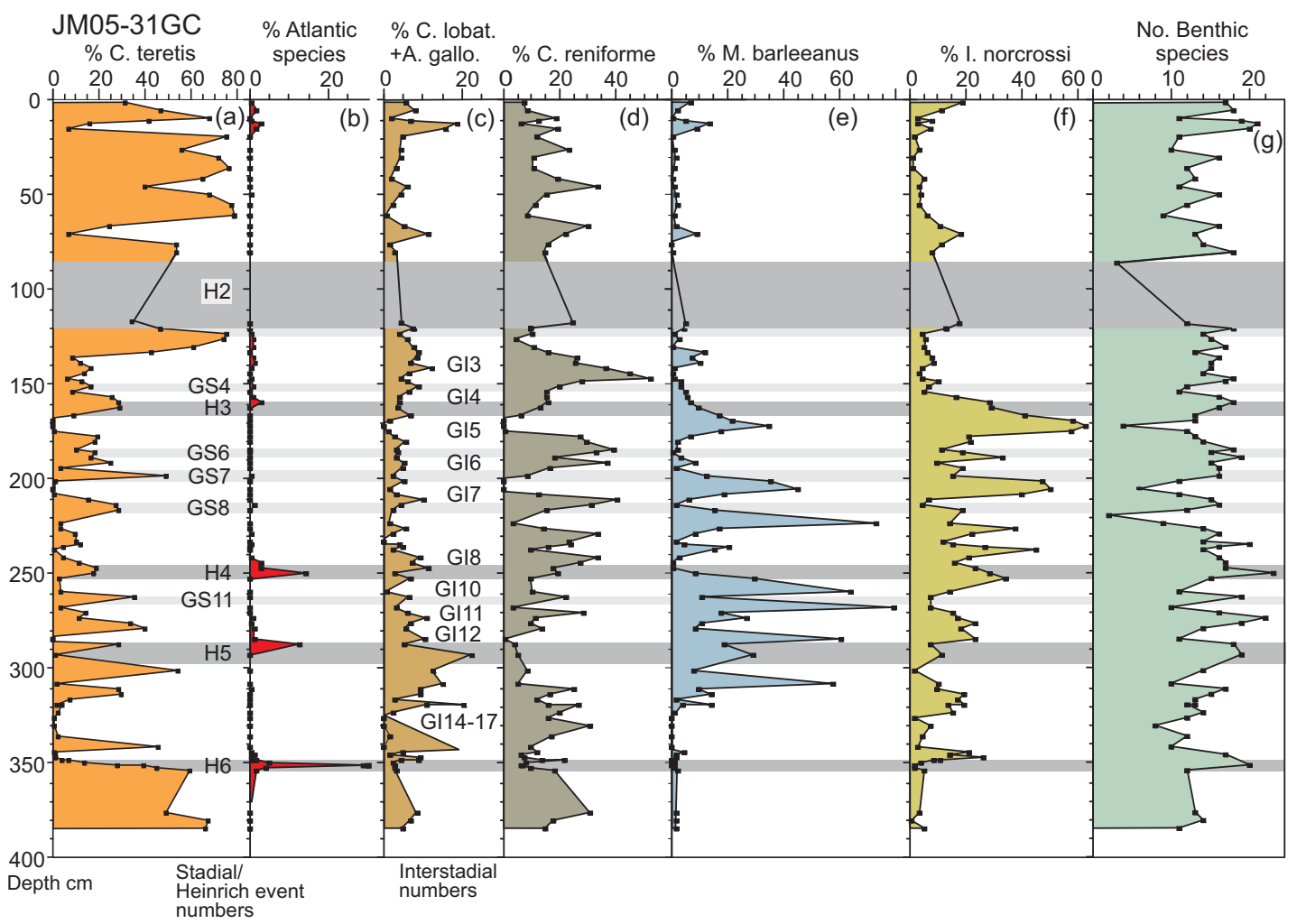

Figure 5. Relative abundances of benthic foraminifera from core JM05-31GC plotted versus centimeter downcore. (a) Cassidulina teretis. (b) The "Atlantic species group" (see text for explanation). (c) Cibicides lobatulus and Astrononion gallowayi added together. (d) C. reniforme. (e) Melonis barleeanus. (f) Islandiella norcrossi. (g) Number of benthic species per sample (simple diversity). Light grey bars mark stadials. Dark grey bars mark Heinrich events. GS and GI numbers are indicated.

MIS 3 are barren of foraminifera or contain foraminifera in very low concentrations (Figure 4). These intervals are characterized by very high proportions of fragmented specimens (Figure 4). Overall, the proportion of fragmentation is relatively low in MIS 4 and MIS 2 and more variable in MIS 3.

[17] The core is characterized by high variability in all the measured parameters (Figures 3-6). The concentration of planktonic foraminifera is generally high in MIS 4 and MIS 2 (except for the barren intervals) and low in MIS 3 (Figure 4). Neogloboquadrina pachyderma s $(>100 \mu \mathrm{m})$ dominates in all samples making up between $57 \%$ and $100 \%$ of the faunas (Figure 4). The most abundant subpolar species is Turborotalita quinqueloba. In general, the percentage of $N$. pachyderma $\mathrm{s}$ and $T$. quinqueloba varies inversely. The concentration of IRD is normally highest in layers with high abundance of $N$. pachyderma s and low abundance of T. quinqueloba (Figure 4).

[18] The distribution patterns of the benthic species also show great variability (Figure 5 ). The most important species are C. teretis, Melonis barleeanus, Cassidulina reniforme, Islandiella norcrossi, Elphidium excavatum. Cibicides lobatulus, and Astrononion gallowayi are present in low abundance with small maxima in the lower part of MIS 3.

[19] The record shows repeated shifts between intervals with low and high $\delta^{18} \mathrm{O}$ and $\delta^{13} \mathrm{C}$ values. The intervals with low isotopic values are further characterized by high percentages of $N$. pachyderma s and $C$. teretis, whereas the intervals with high isotopic values are characterized by relatively high percentages of $T$. quinqueloba, $C$. lobatulus, C. reniforme, M. barleeanus, and I. norcrossi (Figures 4 and 5). High proportions of $C$. teretis are often accompanied by a distinctive group of benthic species termed the "Atlantic species group" (Figure 5). This is a diverse group of species comprising Sigmoilopsis schlumbergeri, Eggerella bradyi, Cibicidoides pachyderma $(=C$. aff. C. floridanus), Discospirina italica, Sigmoilina tenuis, Gyroidinoides spp., and Epistominella decorata (the shallow water form of Alabaminella 


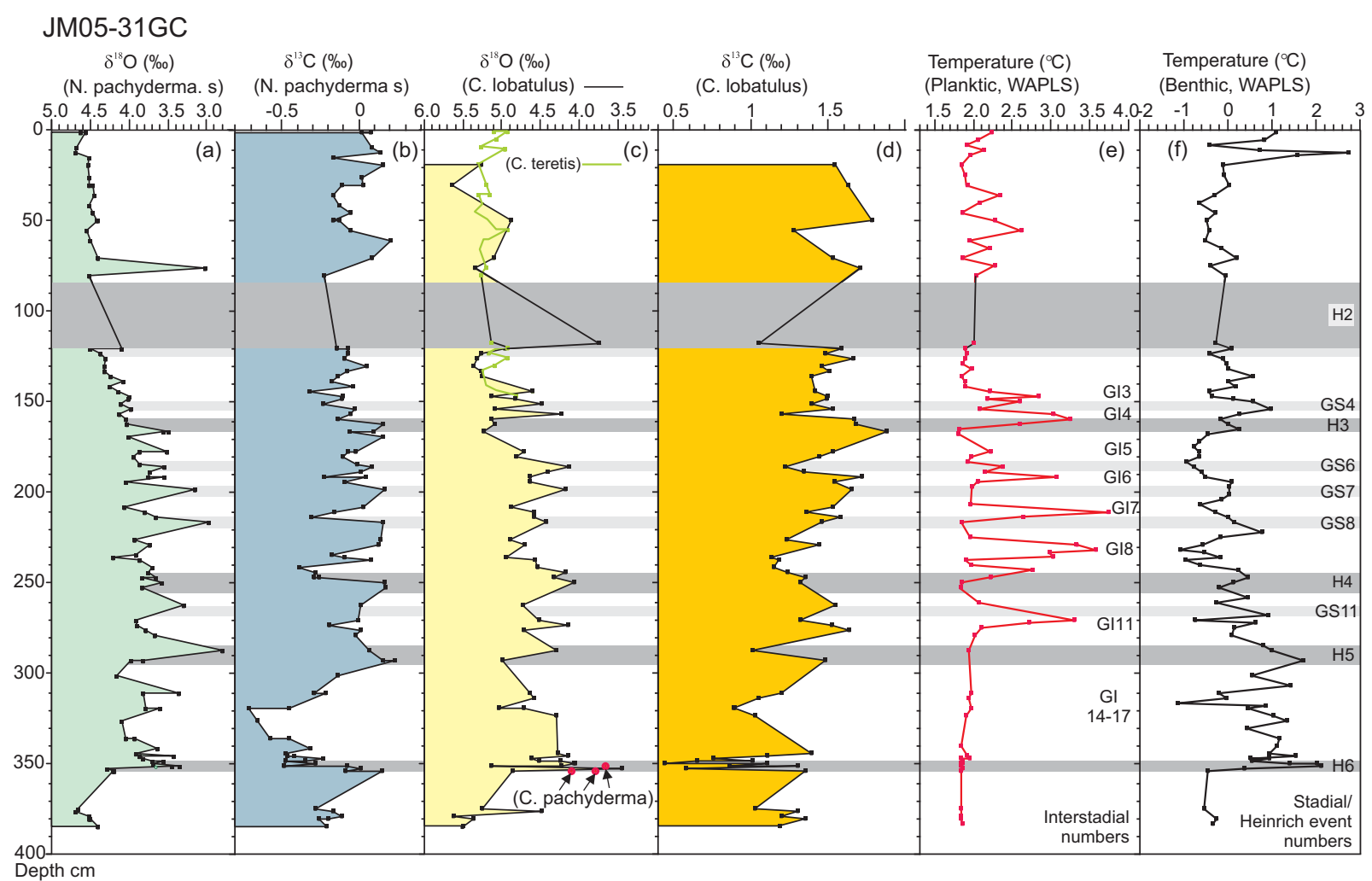

Figure 6. (a) Planktonic $\delta^{18} \mathrm{O}$ values measured in $N$. pachyderma s. (b) Planktonic $\delta^{13} \mathrm{C}$ values measured in N. pachyderma s. (c) Benthic $\delta^{18} \mathrm{O}$ values measured in Cibicides lobatulus (black line, yellow fill), Cassidulina teretis (green line), and Cibicidoides pachyderma (red dots highlighted by arrows). (d) Benthic $\delta^{13} \mathrm{C}$ values measured in Cibicides lobatulus. (e) Subsurface temperatures $(75 \mathrm{~m})$ calculated by transfer functions using the planktonic foraminiferal census counts $>150 \mu \mathrm{m}$. (f) Bottom water temperature calculated by transfer functions using the benthic foraminiferal census counts (see text for details). Light grey bars mark stadials. Dark grey bars mark Heinrich events. GS and GI numbers are indicated.

weddellensis and also referred to as E. nipponica [Rasmussen, 2005]) [see, e.g., Rasmussen et al., 2003, 2007; Mohan et al., 2011]. The species of the "Atlantic species group" is mainly known from intermediate depth in the warm boreal to subtropical Atlantic. It has previously been shown that $C$. teretis and species of the "Atlantic species group" appear in the North Atlantic and in the southern Nordic seas at intermediate depth during stadials and Heinrich events correlating with low benthic and planktonic oxygen isotope values [Rasmussen et al., 1996a, 1996b; Rasmussen and Thomsen, 2004, 2009].

\section{Correlation to Millennial-Scale Events}

[20] The isotopic, foraminiferal, and sedimentological variations in JM05-31GC clearly occur on a millennial timescale (Figures 4-6). Similar pat- terns, shown by the same parameters, have been described from several cores from the North Atlantic and the Nordic seas [e.g., Bond et al., 1993; Fronval et al., 1995; Dokken and Hald, 1996; Rasmussen et al., 1996a, 1996b; Voelker, 2002; Rasmussen and Thomsen, 2004]. The pattern reflects the millennial-scale DansgaardOeschger climate events first described from the Greenland ice cores [e.g., Dansgaard et al., 1993; NGRIP Members, 2004]. Each event consists of a warm interstadial phase and a cold stadial phase. Seventeen prominent Dansgaard-Oeschger events disrupted the climate of MIS 4-MIS 2. In the marine records stadials are characterized by low stable isotope values and interstadials by high values [e.g., Bond et al., 1993] (Figures 4 and 6).

[21] In North Atlantic records from MIS 4 to MIS 2, six stadials stand out as particularly strong. They are termed Heinrich events H6-H1 and characterized by high amounts of IRD, low planktonic $\delta^{18} \mathrm{O}$ values, and dominance of the cold water 
planktonic foraminifera $N$. pachyderma $\mathrm{s}$ [Bond et al., 1993]. Heinrich events in both the North Atlantic and Nordic seas are further characterized by low benthic productivity and high planktonic/ benthic (P/B) ratios [Rasmussen et al., 1996a, 1996b, 2003; Rasmussen and Thomsen, 2008] (Figure 4). In records from the Nordic seas, Heinrich events and especially $\mathrm{H} 6$ and $\mathrm{H} 1$ are conspicuous, because of very low $\delta^{18} \mathrm{O}$ values as compared to other Heinrich events [Bond et al., 1993] and because they contain particularly high proportions of $C$. teretis and the "Atlantic species group" [Rasmussen et al., 1996a, 1996b; Rasmussen and Thomsen, 2004, 2009] (Figure 5).

[22] In marine records $\mathrm{H} 6$ and $\mathrm{H} 5$ are dated to circa 60,000 years B.P. (end of MIS 4; see Figure 3 ) and circa 48,000 years B.P., respectively [Bond et al., 1993; Fronval et al., 1995; Dokken and Hald, 1996; Rasmussen et al., 1996a, 1996b; Elliot et al., 1998]. Heinrich event H4 normally dates around $35,000{ }^{14} \mathrm{C}$ years and occurs just after the end of the Laschamp event, which correlates with the Greenland interstadials 9 and 10 [Laj et al., 2002]. $\mathrm{H} 3$ and $\mathrm{H} 2$ consistently date to circa 27,000-25,000 and 22,000-20,000 ${ }^{14} \mathrm{C}$ years, respectively, in the North Atlantic region [e.g., Bond et al., 1993].

[23] In core JM05-31GC, the intervals from 354 to 350,285 to 288 , and 252 to $245 \mathrm{~cm}$ are characterized by maximum relative abundance of the "Atlantic species group," low $\delta^{18} \mathrm{O}$ values, and high $\mathrm{P} / \mathrm{B}$ ratios (Figures 4 and 5). Combined with the ${ }^{14} \mathrm{C}$ measurements, the calibrated ages, and the age and position of the Laschamps event (Figure 3 ) we correlated these intervals with $\mathrm{H} 6, \mathrm{H} 4$, and H3 (Figures 4-6; see below). Heinrich event H5 is more difficult to pinpoint. We have tentatively placed it at 285 to $288 \mathrm{~cm}$ downcore. Heinrich event $\mathrm{H} 2$ coincides in time with the deposition of the coarse, unsorted sediment layer from 80 to 110 $\mathrm{cm}$ [Jessen et al., 2010]. Similar deposits dated to $22,000-20,000{ }^{14} \mathrm{C}$ years occur widespread on the western margin of Svalbard (see above) [Jessen et al., 2010].

[24] Interstadial and smaller stadial events were identified using the same criteria as discussed above for the Heinrich events. Exact identification and numbering of events were obtained by correlation to the ice core using the location of the identified Heinrich events (Figure 4). The interval with the highest resolution from 170 to $255 \mathrm{~cm}$ was tuned to the ice core using the start and end of the cold stadials and Heinrich events as tie points and assuming linear sedimentation rates between tie points (Figures 3 and 4). Selected data were plotted against the ice core age (Figure 7).

[25] Discrepancies in the calibrated ages of events between core JM05-31GC and the ice core are probably due to either changes in reservoir age with time or to the use of different materials for the datings (benthic and planktonic material may give different results [Voelker et al., 1998]; (Figures 3 and 7 and Table 1). However, the error on the calibrated marine ages for the time interval $30,000-41,000$ years is within the error interval of the North Greenland Ice Core Project (NGRIP) timescale, viz, 600-900 years (Figure 3) [Svensson et al., 2008].

\section{Discussion}

[26] The large variability in the investigated parameters in core JM05-31GC and the correspondence between this variability and the DansgaardOeschger events recorded in the Greenland ice cores indicate that the paleoceanography of the Fram Strait from circa 65,000 to 25,000 years B.P. was strongly affected by these millennial timescale climatic shifts (Figures 3-7). Below we reconstruct the oceanographic development at the core site throughout a typical Dansgaard-Oeschger event from MIS 3. The result is compared to similar reconstructions based on marine cores from the southern Nordic seas in order to investigate if the two areas were influenced by the same or different environmental factors. The reconstruction is synthesized on the basis of Dansgaard-Oeschger events 5-8, which show the highest temporal resolution in the record and share many common characteristics (Figure 7). In the reconstruction, we subdivided the development into three phases following the scheme used in the southern Nordic seas [Rasmussen et al., 1996a, 1996b]: (1) the interstadial phase, (2) the interstadial cooling phase, and (3) the stadial phase.

\subsection{Interstadial Phase}

[27] The high relative abundance of the planktonic foraminifera $N$. pachyderma $\mathrm{s}$, in conjunction with estimated summer subsurface temperatures between $3.5^{\circ} \mathrm{C}$ and $4{ }^{\circ} \mathrm{C}$, indicates a strong influence of warm Atlantic water at the surface (Figures 4,6 , and 7). The benthic foraminifera are dominated by $C$. reniforme, $C$. lobatulus, and Astrononion gallowayi, which points to vigorous bottom currents [Mackensen et al., 1985; 


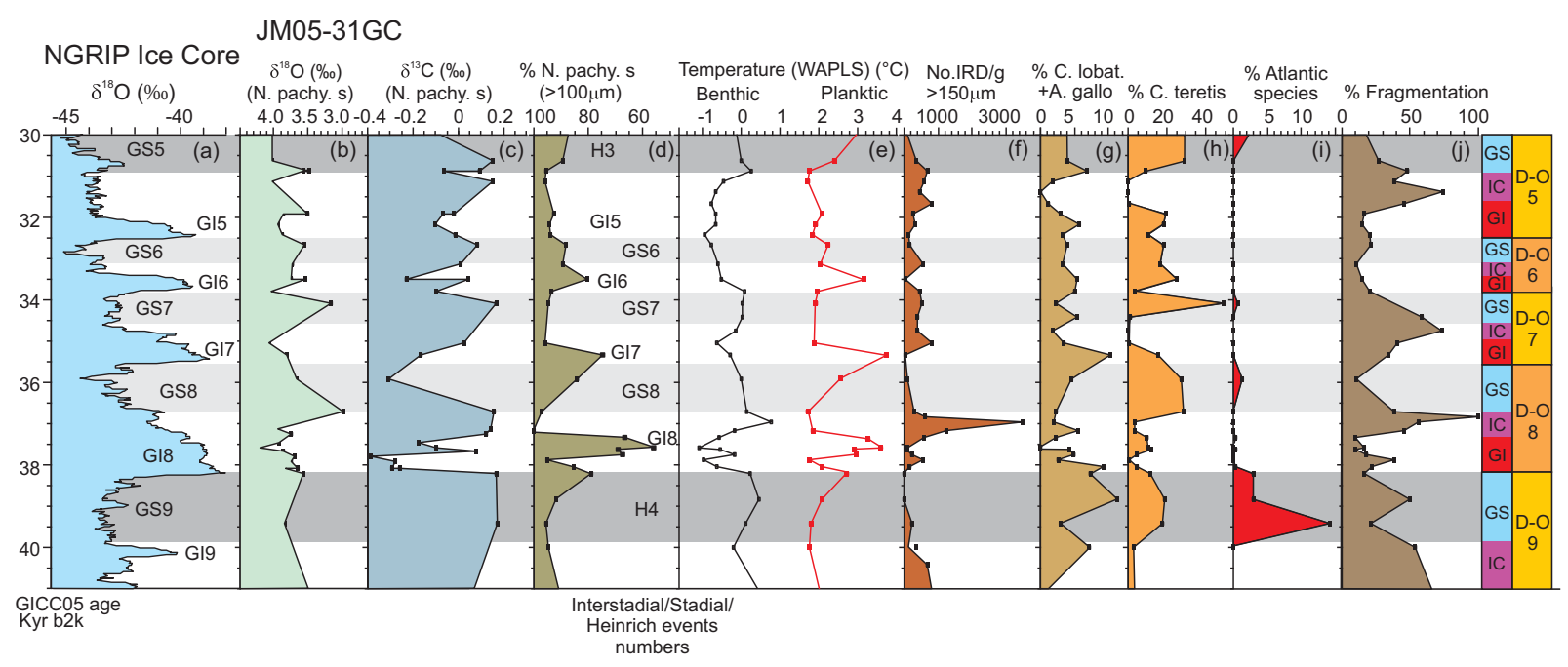

Figure 7. Details of selected parameters from core JM05-31GC plotted versus ice core age (GICC05 years before $2 \mathrm{ka}$ ). (a) $\delta^{18} \mathrm{O}$ values measured on NGRIP ice core on GICC05 timescale before $2 \mathrm{ka}$ [Svensson et al., 2008] (stadial and interstadial numbers are indicated). (b) Planktonic $\delta^{18} \mathrm{O}$ values measured in N. pachyderma s. (c) Planktonic $\delta^{13} \mathrm{C}$ values measured in $N$. pachyderma s. (d) Relative abundance of $N$. pachyderma $\mathrm{s}$ $(>100 \mu \mathrm{m})$ plotted on inverse scale. (e) Subsurface (planktonic) and bottom (benthic) water temperatures calculated by transfer functions. (f) Concentration of IRD $(>150 \mu \mathrm{m})$ in number per gram dwt sediment. (g-i) Relative abundance of selected benthic foraminiferal species. (g) Cibicides lobatulus and Astrononion gallowayi added together. (h) Cassidulina teretis. (i) Atlantic species (see text for explanation). (j) Percent fragmentation (see text for explanation). Light grey bars mark stadials. Dark grey bars mark Heinrich events. Column to the left shows Dansgaard-Oeschger event (D-O) and GS and GI numbers. IC refers to the "interstadial cooling phase" of the interstadials (see text for explanation).

Wollenburg and Mackensen, 1998] (Figures 5-7). Bottom water temperatures were mostly below zero indicating the presence of water masses similar to the modern Greenland Sea Intermediate Water (Figures 1, 6, and 7). The high planktonic and benthic $\delta^{18} \mathrm{O}$ values point to fully marine conditions at both the surface and bottom. Ventilation was good as indicated by the increase in planktonic and benthic $\delta^{13} \mathrm{C}$ values (Figures 6 and 7).

[28] The planktonic and benthic foraminiferal faunas, the planktonic and benthic stable isotope values, and the relatively high subsurface and low bottom water temperatures all indicate that the interstadial water mass distribution and current system in the Fram Strait was similar to the modern system (Figures 6 and 7). Today, warm Atlantic surface water flows northward into the Nordic seas along the coast of Norway. A large proportion continues northward along the slope of Svalbard into the Fram Strait and the Arctic Ocean (Figure 1a). However, a substantial part of the Atlantic water is converted into deep water in the central and western Nordic seas (Figure 1a). About half of the convected water returns to the North Atlantic across the Greenland-Scotland Ridge as cold deep water overflows [Hopkins, 1991]. The remaining part flows northward as Greenland Sea Intermediate and Deep Water and enters the Arctic Ocean below the Atlantic surface water (Figure 1a).

\subsection{Interstadial Cooling Phase}

[29] Poor preservation of biogenic calcite and high percentages of fragmented tests make the interpretation the interstadial cooling phase more challenging (Figures 4 and 7). The phase is almost barren of planktonic foraminifera. A few calculations of sea surface temperature by transfer functions indicate the surface water was colder than during the peak interstadials (Figures 6 and 7). This is in good agreement with a higher concentration of IRD indicating a higher production of icebergs and growing ice sheets or, possibly, more active ice streams [e.g., Winsborrow et al., 2010] (Figures 4 and 7). The benthic faunas are dominated by M. barleeanus and I. norcrossi. Current indicators such as C. lobatulus and A. gallowayi decrease in abundance, and the benthic diversity is low (Figure 5). M. barleeanus, and I. norcrossi are both attracted to areas with a high supply of organic material. I. norcrossi is abundant in high 
productivity zones near the sea ice edges [Steinsund and Hald, 1992]. In the Fram Strait, today, organic productivity is especially high in the Arctic water below the MIZ (Figure 1). The surface water in this zone is a mixture of the northward flowing warm Atlantic Water and the southward flowing very cold Polar Water. The zone is also characterized by strong dissolution and poor preservation of calcareous tests. The dissolution is probably caused by the high content of organic material in the bottom sediments [Gradinger and Baumann, 1991; Hebbeln and Berner, 1993; Hebbeln et al., 1998; Zamelczyk et al., 2012]. The surface water conditions during the interstadial cooling phase must have been very similar to the modern conditions in the Arctic water in the central Fram Strait. The reduction in bottom water flow indicates that the convection in the Nordic seas was decreasing as compared to the interstadials and that the areas of convection moved southward with the sea ice edge [e.g., Rasmussen and Thomsen, 2004].

\subsection{Stadial Phase}

[30] The stadials are first of all characterized by a reversed top to bottom temperature profile as compared to the interstadials (and today; Figures 6 and 7). During interstadials the surface water was warmer than the bottom water; during the stadials the bottom water was warmer than the surface water.

[31] The total dominance of the planktonic foraminifera $N$. pachyderma s (Figure 7) and the relatively high content of IRD indicate cold surface conditions and the presence of common icebergs. However, the content of IRD and the number of icebergs were lower than during the interstadial cooling phase. This may be due to a thicker and more compact layer of sea ice enclosing most of the icebergs along the coast. The low planktonic $\delta^{18} \mathrm{O}$ values are usually interpreted to indicate the presence of meltwater at the surface and a stratified water column [Bond et al., 1993; Simstich et al., 2003].

[32] The presence of $C$. teretis and the "Atlantic species group" together with decreasing benthic $\delta^{18} \mathrm{O}$ values have been interpreted as an indication for increase in bottom water temperatures [see Rasmussen et al., 1996b; Rasmussen and Thomsen, 2004] (Figure 6). This is in agreement with the transfer function calculations, which indicate that the bottom water temperatures increased from between $<-1^{\circ} \mathrm{C}$ and $-0.2^{\circ} \mathrm{C}$ during interstadials to $1.4^{\circ} \mathrm{C}$ to $>2.0^{\circ} \mathrm{C}$ during stadials (Figures 6 and 7). Similar results have been obtained from the Arctic Ocean, where $\mathrm{Mg} / \mathrm{Ca}$ values measured in benthic ostracods indicate a rise in bottom water temperatures in the order of $1-2^{\circ} \mathrm{C}$ during some of the major Heinrich events [Cronin et al., 2012]. It is also in concordance with $\mathrm{Mg} / \mathrm{Ca}$ ratios measured in benthic foraminifera from the North Atlantic Ocean and the Vøring Plateau in the Norwegian Sea, which indicate a rise in bottom water temperatures during Heinrich events in the order of $4-6^{\circ} \mathrm{C}$ [Marcott et al., 2011].

[33] The new results from core JM05-31GC indicate that during cold events the intermediate water warmed all the way from the North Atlantic Ocean to the northernmost Fram Strait. The water cooled underway from $4^{\circ} \mathrm{C}$ to $6^{\circ} \mathrm{C}$ around Faeroe Islands to $\sim 2^{\circ} \mathrm{C}$ at the entrance to the Arctic Ocean. Today, the Atlantic Water at $450 \mathrm{~m}$ water depth cools from $3^{\circ} \mathrm{C}$ to $9^{\circ} \mathrm{C}$ (summer temperatures) between the Faeroe Islands and Scotland to about $2^{\circ} \mathrm{C}$ in the Northern Fram Strait [Chatwin et al., 2001] (Figure 1).

[34] The planktonic and benthic $\delta^{13} \mathrm{C}$ values in core JM05-31GC are generally low in stadials and Heinrich events (as resolution allows; Figures 4 and 5). In records from the northeastern North Atlantic Ocean and southern Nordic seas the planktonic values are similarly low, while the benthic values are only low in Heinrich events [Peck et al., 2007; Rasmussen and Thomsen, 2009]. The low planktonic $\delta^{13} \mathrm{C}$ values are generally explained by surface stratification due to the presence of meltwater creating a meltwater lid. Several interpretations have been proposed for the low benthic $\delta^{13} \mathrm{C}$ values [e.g., Waelbroeck et al., 2006, and references therein; Peck et al., 2007; Rasmussen and Thomsen, 2009]. Rasmussen and Thomsen [2009] proposed that the most likely explanation was "aging" of the intermediate water as the warmer subducted Atlantic Water flowed northward below the meltwater layer. The lower values in the Heinrich events as compared to the stadials suggest that the subduction occurred in a more southerly position during Heinrich events than during the stadials. During Heinrich events the subduction most likely occurred in the North Atlantic south of the Heinrich Belt [Rasmussen and Thomsen, 2004, 2009]. During stadials the subduction was mostly located north of the Heinrich Belt. Today, the Atlantic Water is subducted at the northern end of the Fram Strait only about 50-100 km 
north of the coring site of JM05-31GC [e.g., Rudels et al., 2000, 2005].

\section{Conclusions}

[35] Our results show that there was continuous exchange of water masses through the Fram Strait during MIS 4-MIS 2. However, the strength and temperatures of the water masses flowing into the Arctic Ocean varied considerably and probably in pace with the millennial timescale interstadialstadial climate changes observed in the Greenland ice cores.

\subsection{Interstadials}

[36] Several investigations from the southeastern Nordic seas have shown that during the interstadials warm Atlantic surface water flowed north into the Nordic seas. This study shows that this warm surface water reached the northern end of the Fram Strait and that the inflow of warm Atlantic Water to the Arctic Oceans must have been almost as today. During interstadials, as today, parts of the Atlantic Water entering the Nordic seas are convected into cold deep water. Temperature calculations by transfer functions estimate subsurface (75 $\mathrm{m}$ water depth) temperatures at the study site around $3.5^{\circ} \mathrm{C}$ and bottom water temperatures between $-1^{\circ} \mathrm{C}$ and $0^{\circ} \mathrm{C}$. These temperatures are close to the present temperatures. The benthic faunas and the planktonic and benthic $\delta^{13} \mathrm{C}$ values indicate good ventilation and strong bottom water currents.

\subsection{Interstadial Cooling Phase}

[37] The warm interstadial phases lasted only a few hundred years according to the age model and the ice core records. After the short maximum warmth the Arctic surface water and the marginal ice zone began to expand causing a cooling of the surface water over the core site. Ice rafting in the northern Fram Strait increased rapidly. Convection areas probably moved southward, and the formation of cold intermediate water probably decreased. The interstadial cooling phases are characterized by poor preservation of calcareous material, and our knowledge of these periods in the Fram Strait is relatively poor.

\subsection{Stadials and Heinrich Events}

[38] During the cold events the upper water masses in the Fram Strait became stratified with a perma- nent or near-permanent sea ice cover. The sea ice edge of the Arctic Ocean was pushed further southward. The subduction of the Atlantic Water, which today occurs just north of the Fram Strait, followed the front of the permanent ice cover. Convention in the Greenland Sea came to a stop or near-stop. In the Nordic seas and in the Fram Strait, Atlantic Water continued to flow, but now as a subsurface intermediate water mass comparable to inflow of Atlantic Intermediate Water into the Arctic Ocean today. In the Fram Strait the intermediate water warmed $>2^{\circ} \mathrm{C}$ as compared to the interstadial and present temperatures. The benthic foraminiferal faunas were dominated by Cassidulina teretis and species with a southern affinity. Differences between Heinrich events and the smaller stadial events in the benthic $\delta^{13} \mathrm{C}$ values of the Atlantic Intermediate Water indicate that the subduction zone was located in a more southerly position during Heinrich events than during stadials.

\section{Acknowledgments}

[39] We thank the captain and crew of RV Jan Mayen for their assistance in the core retrieval. The research was supported by the University of Tromsø and the Mohn Foundation to the "Paleo-CIRCUS" project and by the Research Council of Norway (Centre of Excellence funding scheme, grant 223259/F5). We are grateful to S. B. Andersen for careful proofreading of this manuscript and figures.

\section{References}

Aagaard, K., A. Foldvik, and S. R. Hillman (1987), The West Spitsbergen Current: Disposition and water mass transformation, J. Geophys. Res., 92, 3778-3784.

Andersen, E. S., T. M. Dokken, A. Elverhøi, A. Solheim, and I. Fossen (1996), Late Quaternary sedimentation and glacial history of the Western Svalbard continental margin, Mar. Geol., 133, 123-156.

Antonov, M., P. M. Goldschmidt, and H. Erlenkeuser (1997), The climate-sensitive Vesterisbanken area (central Greenland Sea): Depositional environment and paleoceanography during the past 250,000 years, in Contributions to the Micropaleontology and Paleoceanography of the Northern North Atlantic, Spec. Publ. 5, edited by H. C. Hass and M. A. Kaminski, pp. 101-118, The Grzybowski Found, London, U. K.

Austin, W. E. N., and J. R. Evans (2000), NE Atlantic benthic foraminifera: Modern distribution patterns and palaeontological significance, J. Geol. Soc. London, 157, 679-691.

Bauch, H. A. (1997), Paleoceanography of the North Atlantic Ocean $(68-76 \mathrm{~N})$ during the past $450 \mathrm{ky}$ deduced from planktic foraminiferal assemblages and stable isotopes, in Contributions to the Micropaleontology and Paleoceanography of the Northern North Atlantic, Spec. Publ. 5, edited 
by H. C. Hass and M. A. Kaminski, pp. 83-100, The Grzybowski Found, London, U. K.

Bauch, H. A., H. Erlenkeuser, R. F. Spielhagen, U. Struck, J. Matthiessen, J. Thiede, and J. Heinemeier (2001), A multiproxy reconstruction of the evolution of deep and surface waters in the subarctic Nordic seas over the last 30,000 yr, Quat. Sci. Rev., 20, 659-678.

Belanger, B. E., and S. S. Streeter (1980), Distribution and ecology of benthic foraminifera in the NorwegianGreenland Sea, Mar. Micropaleontol., 5, 401-428.

Berger, W. H., M. C. Bonneau, and F. L. Parker (1982), Foraminifera on the deep-sea floor: Lysocline and dissolution rate, Oceanol. Acta, 5, 249-258.

Birks, H. J. B. (1998), Numerical tools in palaeolimnologyProgress, potentialities, and problems, J. Paleolimnol., 20, 307-332.

Bond, G., W. S. Broecker, S. J. Johnsen, J. McManus, L. Labeyrie, J. Jouzel, and G. Bonani (1993), Correlations between climate records from North Atlantic sediments and Greenland ice, Nature, 365, 143-147.

Broecker, W. S., G. Bond, and M. Klas (1990), A salt oscillator in the glacial Atlantic?: 1. The concept, Paleoceanography, 5, 469-477, doi:10.1029/PA005i004p00469.

Chatwin, P. G., W. R. Turrell, P. I. Miller, G. Slesser, S. Hughes, and P. Gillibrand (2001), Mesoscale variability in the Faroe-Shetland Channel during FRV Scotia Cruise 1600S, 5-19 October 2000, Rep. 02/01, 59 pp., Mar. Lab., Fish. Res. Serv., Aberdeen, U. K.

Conan, S. M. H., E. M. Ivanova, and G. J. A. Brummer (2002), Quantifying carbonate dissolution and calibration of foraminiferal dissolution indices in the Somali Basin, Mar. Geol., 182, 325-349.

Corliss, B. H. (1991), Morphology and microhabitat preferences of benthic foraminifera from the northwest Atlantic Ocean, Mar. Micropaleontol., 17, 195-236.

Cronin, T. M., G. S. Dwyer, J. Farmer, H. A. Bauch, R. F. Spielhagen, M. Jakobsson, J. Nilsson, W. M. Briggs Jr., and A. Stepanova (2012), Deep Arctic Ocean warming during the last glacial cycle, Nat. Geosci., 5, 631-634.

Dansgaard, W., et al. (1993), Evidence for general instability of past climate from a 250-kyr ice-core record, Nature, 364, 218-220.

Dokken, T. M., and M. Hald (1996), Rapid climatic shifts during isotope stages 2-4 in the Polar North Atlantic, Geology, 24, 599-602.

Duros, P., C. Fontanier, E. Metzger, A. Pusceddu, F. Cesbron, H. C. de Stigter, S. Bianchelli, R. Danovaro, and F. J. Jorissen (2011), Live (stained) benthic foraminifera in the Whittard Canyon, Celtic margin (NE Atlantic), Deep Sea Res., Part I, 58, 128-146.

Eiken, O., and K. Hinz (1993), Contourites in the Fram Strait, Sed. Geol., 82, 15-32.

Elliot, M., L. Labeyrie, G. Bond, E. Cortijo, J.-L. Turon, N. Tisnerat, and J.-C. Duplessy (1998), Millennial-scale iceberg discharges in the Irminger basin during the last glacial period: Relationship with the Heinrich events and environmental settings, Paleoceanography, 13, 433-446, doi: 10.1029/98PA01792.

Elverhøi, A., E. S. Andersen, T. Dokken, D. Hebbeln, R. Spielhagen, J. I. Svendsen, M. Sørflaten, A. Romes, M. Hald, and C. F. Forsberg (1995), The growth and decay of the Late Weichselian ice sheet in western Svalbard and adjacent areas based on provenance studies of marine sediments, Quat. Res., 44, 303-316.
Fontanier, C., F. J. Jorissen, L. Licari, A. Alexandre, P. Anschutz, and P. Carbonel (2002), Live benthic foraminiferal faunas from the Bay of Biscay: Faunal density, composition, and microhabitats, Deep Sea Res., Part I, 49, 751-785.

Fronval, T., E. Jansen, J. Bloemendal, and S. J. Johnsen (1995), Oceanic evidence for coherent fluctuations in Fennoscandian and Laurentide ice sheets on millennium timescales, Nature, 374, 443-446.

Gradinger, R. R., and M. E. M. Baumann (1991), Distribution of phytoplankton communities in relation to the large-scale hydrographical regime in the Fram Strait, Mar. Biol., 111, 311-321.

Haake, F.-W., and U. Pflaumann (1989), Late Pleistocene foraminiferal stratigraphy on the Vöring Plateau, Norwegian Sea, Boreas, 18, 343-356.

Hald, M., and P. I. Steinsund (1992), Distribution of surface sediment benthic foraminifera in the southwestern Barents Sea, J. Foram. Res., 22, 347-362.

Hanslik, D., M. Jacobsson, J. Backman, S. Björck, E. Sellén, M. O’Regan, E. Fornaciari, and G. Skog (2010), Quaternary Arctic Ocean sea ice variations and radiocarbon reservoir age corrections, Quat. Sci. Rev., 29, 3430-3441.

Hebbeln, D., and H. Berner (1993), Surface sediment distribution in the Fram Strait, Deep Sea Res., Part I, 40, 17311745.

Hebbeln, D., T. Dokken, E. S. Andersen, M. Hald, and A. Elverhøi (1994), Moisture supply for northern ice sheet growth during the last Glacial Maximum, Nature, 370, 357-360.

Hebbeln, D., R. Henrich, and K. H. Baumann (1998), Paleoceanography of the last interglacial/glacial cycle in the Polar North Atlantic, Quat. Sci. Rev., 17, 125-153.

Heinrich, H. (1988), Origin and consequences of cyclic ice rafting in the Northeast Atlantic Ocean during the past 130,000 years, Quat. Res., 29, 142-152.

Hemleben, C., M. Spindler, and O. R. Anderson (1989), Modern Planktonic Foraminifera, 363 pp., Springer, New York.

Hermelin, O. J., and D. B. Scott (1985), Recent benthic foraminifera from the central North Atlantic Ocean, Micropalaeontology, 31, 199-220.

Hop, H., S. Falk-Petersen, H. Svendsen, S. Kwasniewski, V. Pavlov, O. Pavlova, and J. E. Søreide (2006), Physical and biological characteristics of the pelagic system across Fram Strait to Kongsfjorden, Prog. Oceanogr., 71, 182-231.

Hopkins, T. S. (1991), The GIN-Sea-A synthesis of its physical oceanography and literature review 1972-1985, EarthSci. Rev., 30, 175-318.

Howe, J. A., T. M. Shimmield, and R. Harland (2008), Late Quaternary contourites and glaciomarine sedimentation in the Fram Strait, Sedimentology, 55, 179-200.

Jessen, S. P., T. L. Rasmussen, T. Nielsen, and A. Solheim (2010), A new Late Weichselian and Holocene marine chronology for the western Svalbard slope 30,000-0 cal years BP, Quat. Sci. Rev., 29, 1301-1312.

Johnsen, S. J., D. Dahl-Jensen, N. Gundestrup, J.-P. Steffensen, H. P. Clausen, H. Miller, V. Masson-Delmotte, A. E. Sveinsbjornsdottir, and J. White (2001), Oxygen isotope and palaeotemperature records from six Greenland icecore stations: Camp Century, Dye-3, GRIP, GISP2, Renland and NorthGRIP, J. Quat. Sci., 16, 299-307.

Juggins, S. (2007), C2 Version 1.5 User Guide. Software for Ecological and Palaeoecological Data Analysis and Visualization, Newcastle Univ., Newcastle upon Tyne, U. K.

Knies, J., C. Vogt, and R. Stein (1999), Late Quaternary growth and decay of the Svalbard/Barents Sea ice sheet and 
paleoceanographic evolution in the adjacent Arctic Ocean, Geo Mar. Lett., 18, 195-202.

Kucera, M., et al. (2005), Reconstruction of sea-surface temperatures from assemblages of planktonic foraminifera: Multi-technique approach based on geographically constrained calibration data sets and its application to glacial Atlantic and Pacific Oceans, Quat. Sci. Rev., 24, 951-998.

Laj, C., C. Kissel, V. Scao, J. Beer, D. M. Thomas, H. Guillou, R. Muscheler, and G. Wagner (2002), Geomagnetic intensity and inclination variations at Hawaii for the past $98 \mathrm{kyr}$ from core SOH-4 (Big Island): A new study and a comparison with existing contemporary data, Phys. Earth Planet. Inter., $129,205-243$.

Le, J., and N. J. Shackleton (1992), Carbonate dissolution fluctuations in the western equatorial Pacific during the late Quaternary, Paleoceanography, 7, 21-42.

Locarnini, R. A., A. V. Mishonov, J. I. Antonov, T. P. Boyer, H. E. Garcia, O. K. Baranova, M. M. Zweng, and D. R. Johnson (2010), World Ocean Atlas 2009, vol. 1, Temperature, NOAA Atlas NESDIS 68, edited by S. Levitus, 184 pp., U.S. Gov. Print. Off., Washington, D. C.

Mackensen, A. (1985), Verbreitung und Umwelt benthischer Foraminiferen in der Norwegischen See, PhD thesis, 143 pp., Christian-Albrechts-Univ., Kiel, Germany.

Mackensen, A., H. P. Sejrup, and E. Jansen (1985). The distribution of living benthic foraminifera on the continental slope and rise off southwest Norway, Mar. Micropaleontol., 9, 275-306.

Marcott, S. A., et al. (2011), Ice-shelf collapse from subsurface warming as a trigger for Heinrich events, Proc. Natl. Acad. Sci. U. S. A., 108, 13,415-13,419.

Margreth, S., A. Rüggeberg, and S. Spezzaferri (2009), Benthic foraminifera as bioindicator for cold-water coral reef ecosystems along the Irish margin, Deep Sea Res., Part I, 56, 2216-2234.

Martinson, D. G., N. G. Pisias, J. D. Hays, J. Imbrie, T. C. Moore, and N. J. Shackleton (1987), Age dating and orbital theory of the ice ages: Development of a high resolution 0 300,000-year chronostratigraphy, Quat. Res., 27, 1-29.

McManus, J. F., R. Francois, J.-M. Gherardi, L. D. Keigwin, and S. Brown-Leger (2004), Collapse and rapid resumption of Atlantic meridional circulation linked to deglacial climate changes, Nature, 428, 834-837.

Mohan, K., A. K. Gupta, and A. K. Bhaumik (2011), Distribution of deep-sea benthic foraminifera in the Neogene of Blake Ridge, NW Atlantic Ocean, J. Micropalaeontol., 30, 33-74.

Mojtahid, M., C. Griveaud, C. Fontanier, P. Anschutz, and F. J. Jorissen (2010), Live benthic foraminiferal faunas along a bathymetrical transect $(140-4800 \mathrm{~m})$ in the Bay of Biscay (NE Atlantic), Rev. Micropaléontol., 53, 139-162.

NGRIP Members (2004), High-resolution record of Northern Hemisphere climate extending into the last interglacial period, Nature, 431, 147-151.

Ostermann, D. R., and W. D. Curry (2000), Calibration of stable isotope data: An enriched $\delta^{18} \mathrm{O}$ standard used for source gas mixing detection and correction, Paleoceanography, 15, 353-360.

Peck, V. L., I. R. Hall, R. Zahn, and J. D. Scourse (2007), Progressive reduction in NE Atlantic intermediate water ventilation prior to Heinrich events: Response to NW European ice sheet instabilities?, Geochem. Geophys. Geosyst., 8, Q01N10, doi:10.1029/2006GC001321.
Pflaumann, U., et al. (2003), Glacial North Atlantic: Seasurface conditions reconstructed by GLAMAP 2000, Paleoceanography, 18(3), 1065, doi:10.1029/2002PA000774.

Pfuhl, H. A., and N. J. Shackleton (2004), Two proximal, high-resolution records of foraminiferal fragmentation and their implications for changes in dissolution, Deep Sea Res., Part I, 51, 809-832.

Rasmussen, T. L. (2005), Systematic paleontology and ecology of benthic foraminifera from the Plio-Pleistocene Kalithea Bay Section, Rhodes (Greece), Cushman Found. Spec. Publ., 39, 53-157.

Rasmussen, T. L., and E. Thomsen (2004), The role of the North Atlantic Drift in the millennial timescale glacial climate fluctuations, Palaeogeogr. Palaeoclim. Palaeoecol., 210, 101-116.

Rasmussen, T. L., and E. Thomsen (2008), Warm Atlantic surface water inflow to the Nordic seas $34-10$ calibrated ka B.P., Paleoceanography, 23, PA1201, doi:10.1029/ 2007PA001453.

Rasmussen, T. L., and E. Thomsen (2009), Ventilation changes in intermediate water on millennial time scales in the SE Nordic seas, 65-14 kyr BP, Geophys. Res. Lett., 36, L01601, doi:10.1029/2008GL036563.

Rasmussen, T. L., E. Thomsen, T. C. E. van Weering, and L. Labeyrie (1996a), Rapid changes in surface and deep water conditions at the Faroe margin during the last 58,000 years, Paleoceanography, 11, 757-771.

Rasmussen, T. L., E. Thomsen, L. Labeyrie, and T. C. E. van Weering (1996b), Circulation changes in the FaeroeShetland Channel correlating with cold events during the last glacial period (58-10 ka), Geology, 24, 937-940.

Rasmussen, T. L., E. Thomsen, S. R. Troelstra, A. Kuijpers, and M. A. Prins (2003), Millennial-scale glacial variability versus Holocene stability: Changes in planktic and benthic foraminifera faunas and ocean circulation in the North Atlantic during the last 60,000 years, Mar. Micropaleontol., 47, 143-176.

Rasmussen, T. L., E. Thomsen, M. A. Ślubowska, S. Jessen, A. Solheim, and N. Koç (2007), Paleoceanographic evolution of the SW Svalbard margin $\left(76^{\circ} \mathrm{N}\right)$ since $20,000{ }^{14} \mathrm{C}$ yr BP, Quat. Res., 67, 100-114.

Reimer, P. J., et al. (2009), IntCa109 and Marine09 radiocarbon age calibration curves, 0-50,000 years cal BP, Radiocarbon, 51, 1111-1150.

Rudels, B. (1987), On the mass balance of the Polar Ocean, with special emphasis on the Fram Strait, Norw. Polar Inst. Skr., $188,53 \mathrm{pp}$.

Rudels, B., R. Meyer, E. Fahrbach, V. V. Ivanov, S. Østerhus, D. Quadfasel, U. Schauer, V. Tverberg, and R. A. Woodgate (2000), Water mass distribution in Fram Strait and over the Yermak Plateau in summer 1997, Ann. Geophys., 18, 687-705.

Rudels, B., G. Björk, J. Nilsson, P. Winsor, I. Lake, and C. Nohr (2005), The interaction between waters from the Arctic ocean and the Nordic seas north of Fram Strait and along the East Greenland Current: Results from the Arctic Ocean-02 Oden expedition, J. Mar. Syst., 55, 1-30.

Saher, M., D. Klitgaard Kristensen, M. Hald, S. Korsun, and L. L. Jørgensen (2009), Benthic foraminifera assemblages in the Central Barents Sea: An evaluation of the effects of combining live and total fauna studies in tracking environmental change, Norw. J. Geol., 89, 149-161.

Schönfeld, J. (2002), Recent benthic foraminiferal assemblages in deep high-energy environments from the Gulf of Cadiz (Spain), Mar. Micropaleontol., 44, 141-162. 
Seiler, W. C. (1975), Tiefenverteilung benthischer Foraminiferen am Portugiesischen Kontinentalanhang, "Meteor" Forsch.-Ergebn. C, 23, 47-94.

Sejrup., H.-P., T. Fjæran, M. Hald, L. Beck, J. Hagen, I. Miljeteig, I. Morvik, and O. Norvik (1981), Benthonic foraminifera in surface samples from the Norwegian continental margin between $62^{\circ} \mathrm{N}$ and $65^{\circ} \mathrm{N}, J$. Foram. Res., 11, 277295.

Sejrup, H. P., H. J. B. Birks, D. Klitgaard Kristensen, and H. Madsen (2004), Benthonic foraminiferal distributions and quantitative transfer functions for the northwest European continental margin, Mar. Micropaleontol., 53, 197-226.

Schafer, C. T., and F. E. Cole (1982), Living benthic foraminifera distributions on the continental slope and rise of Newfoundland, Canada, Geol. Soc. Am. Bull., 93, 207-217.

Schröder-Adams, C. J., and D. van Rooyen (2011), Response of recent benthic foraminiferal assemblages to contrasting environments in Baffin Bay and the northern Labrador Sea, Northwest Atlantic, Arctic, 64, 317-341.

Shackleton, N. J. (1974), Attainment of isotopic equilibrium between ocean water and the benthonic foraminifera Uvigerina: Isotopic changes in the ocean during the last glacial, Colloq. Int. Cent. Natl. Rech. Sci., 219, 203-209.

Simstich, J., M. Sarnthein, and H. Erlenkeuser (2003), Paired $\delta^{18} \mathrm{O}$ signals of $N$. pachyderma (s) and T. quinqueloba show thermal stratification structure in the Nordic seas, Mar. Micropaleontol., 48, 107-125.

Spielhagen, R. F., K.-H. Baumann, H. Erlenkeuser, N. R. Nowaczyk, N. Nørgaard-Pedersen, C. Vogt, and D. Weiel (2004), Arctic Ocean deep-sea record of northern Eurasian ice sheet history, Quat. Sci. Rev., 23, 1455-1483.

Smith, W. O., Jr., M. E. M. Baumann, D. L. Wilson, and L. Aletsee (1987), Phytoplankton biomass and productivity in the marginal ice zone of the Fram Strait during summer 1984, J. Geophys. Res., 92, 6777-6786.

Snowball, I., A. Nilsson, and T. Rasmussen (2007), Late Quaternary geomagnetic excursions at high northern latitudes in marine sediments: Reproducing results for the wrong reasons?, Eos Trans. AGU, 88(52), Fall Meet. Suppl., Abstract GP21A-0099.

Stuiver, M., and P. J. Reimer (1993), Extended ${ }^{14} \mathrm{C}$ database and revised CALIB radiocarbon calibration program, Radiocarbon, 35, 215-230.

Sun, X., B. H. Corliss, C. W. Brown, and W. J. Showers (2006), The effect of primary productivity and seasonality on the distribution of deep-sea benthic foraminifera in the North Atlantic, Deep Sea Res., Part I, 53, 28-47.
Svensson, A., et al. (2008), A 60000 year Greenland stratigraphic ice core chronology, Clim. Past, 4, 47-57.

van Kreveld, S., M. Sarnthein, H. Erlenkeuser, P. Grootes, S. Jung, M. J. Nadeau, U. Pflaumann, and A. Voelker (2000), Potential links between surging ice sheets, circulation changes, and the Dansgaard-Oeschger cycles in the Irminger Sea, 60-18 kyr, Paleoceanography, 15, 425-442.

Vinje, T. E. (1977), Sea ice conditions in the European sector of the marginal seas of the Arctic, 1966-75, Norw. Polar Inst., 1975, 163-174.

Voelker, A. H. L. (2002), Global distribution of centennialscale records for marine isotope stage (MIS) 3: A database, Quat. Sci. Rev., 21, 1185-1212.

Voelker, A. H. L., M. Sarnthein, P. Grootes, H. Erlenkeuser, C. Laj, A. Mazaud, M.-J. Nadeau, and M. Schleicher (1998), Correlation of marine 14-C ages from the Nordic seas with the GISP2 isotope record: Implications for 14-C calibration beyond $25 \mathrm{ka} \mathrm{BP}$, Radiocarbon, 40, 517-534.

Vogt, C., J. Knies, R. F. Spielhagen, and R. Stein (2001), Detailed mineralogical evidence for two nearly identical glacial-deglacial cycles and Atlantic water advection to the Arctic Ocean during the last 90,000 years, Global Planet. Change, 31, 23-44.

Waelbroeck, C., C. Levi, J. C. Duplessy, L. Labeyrie, E. Michel, E. Cortijo, F. Bassinot, and F. Guichard (2006), Distant origin of circulation changes in the Indian Ocean during the last deglaciation, Earth Planet. Sci. Lett., 243, 244-251.

Weston, J. F. (1985), Comparison between recent benthic foraminiferal faunas of the Porcupine Seabight and western approaches continental slope, J. Micropalaeontol., 4, 165183.

Winsborrow, M., K. Andreassen, G. D. Corner, and J. S. Laberg (2010), Deglaciation of a marine-based ice sheet: Late Weichselian palaeo-ice dynamics and retreat in the southern Barents Sea reconstructed from onshore and offshore glacial geomorphology, Quat. Sci. Rev., 29, 424-442.

Wollenburg, J. E., and A. Mackensen (1998), Living benthic foraminifers from the central Arctic Ocean: Faunal composition, standing stock and diversity, Mar. Micropaleontol., 34, 153-185.

Zamelczyk, K., T. L. Rasmussen, K. Husum, H. Haflidason, A. de Vernal, E. K. Ravna, M. Hald, and C. Hillaire-Marcel (2012), Between two oceanic fronts: Paleoceanographic changes and calcium carbonate dissolution in the central Fram Strait during the last 20,000 years, Quat. Res., 78, 405-416. 